\author{
Animal Review \\ 2021 Vol. 8, No. 1, pp. 10-19. \\ $\operatorname{ISSN}(e): 2409-6490$ \\ $\operatorname{ISSN}(p): 2412-3382$ \\ DOI: 10.18488/journal.ar.2021.81.10.19 \\ (C) 2021 Conscientia Beam. All Rights Reserved. \\ check for
updates
}

\title{
DIETARY INCLUSION OF SCENT LEAF MEAL (Ocimum Gratissimum) AFFECTS IMMUNE GENES EXPRESSION IN CHICKEN SPLEEN AT 28 AND 56DAYS
}

\author{
Ufuoma G. \\ Sorhue $^{1+}$ \\ Emenim R. \\ Onainor $^{2}$ \\ Adimabua M. \\ Moemeka $^{3}$ \\ Irikefe-Ekeke E. \\ Peterson $^{4}$
}

\author{
${ }^{1,2, s}$ Department of Agricultural Education, Delta State College of Education \\ Mosogar, Sapele, Nigeria. \\ 'Email: gtsorhue@yahoo.com Tel: +2347036311884 \\ ${ }^{2}$ Department of Agricultural Education, College of Education Warri, \\ Nigeria.
}

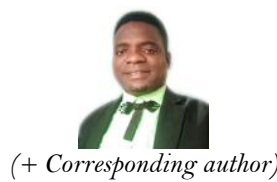

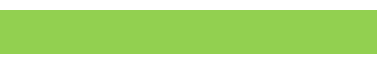

Article History

Received: 2 August 2021 Revised: 30 August 2021

Accepted: 21 September 2021

Published: 11 October 2021

\section{Keywords}

Inflammation

Gene Expression

Interleukin $1 \beta$

Scent leaf

Cytokine

Spleen

Phytochemicals.

\begin{abstract}
This study was conducted to examine the effects of scent leaf meal (Ocimum gratissimum) on expression of inflammatory cytokines in the spleen of two chicken strains. A total of $150 \mathrm{birds}$ ( 75 of each strain) were randomly allotted into five dietary treatments at fifteen birds per treatment. Birds were fed diet containing varying levels of Ocimum gratissimum leaf meal. Treatment one (T1) had $0 \%$ OG, while treatment two (T2), treatment three (T3), treatment four (T4) and treatment five (T5) had $0.5 \%$ OG, $1.00 \%$ OG, $1.5 \%$ OG and $2 \%$ OG respectively. Feed and water was provided adlibitum throughout the feeding trial. Three birds were slaughtered from each treatment at day 28 and day 56, spleen samples were collected and stored using RNALater in a $-20^{\circ} \mathrm{C}$ freezer prior to RNA extraction. Real-time qPCR was performed in 40cycles using the PowerUp SYBR Green reagent and analyzed with the $2^{-\Delta \Delta \mathrm{Ct}}$ method. Gene expression data were subjected to two-way analysis of variance. Strain effect was significantly different $(\mathrm{P}<0.05)$ at both time points. All the genes studied significantly differed $(\mathrm{P}<0.05)$ in their expression patterns at 28 and 56days of age. Increased inclusion rate of the test ingredients significantly $(\mathrm{P}<0.05)$ reduced IL1 $\beta$ and NF-KB1, while increasing IL10 and NF-KB2. Ocimim gratissimum leaf meal shows promise in the regulation of inflammation in chickens and can be used to efficiently replace antibiotics in broiler production.
\end{abstract}

Contribution/Originality: This work is one of very few studies that have unraveled expression patterns of inflammatory cytokines in chickens subjected to dietary inclusion of scent leaf meal as replacement for in-feed antibiotic, and contributes to existing literature on the role of phytochemical containing plants in immunomodulation in chickens.

\section{INTRODUCTION}

Any direct or indirect damage of intestinal epithelial cells may cause a breakdown in gut barrier and consequentially disruption of normal mucosal immune balance that can potentially lead to uncontrolled chronic intestinal and systemic inflammation [1]. Inflammation necessitates cells to hire more cells to the centre of activity by the way of secreting inflammatory cytokines and chemokines, however, delayed inflammation can cause the 
animals to lose weight due to high energy expended in the process [2]. Phytochemicals have been reported to reduce cytokine gene expression IL1 $\beta$, IL6 and TNF (Pro-inflammatory cytokines) and increase IL-10 (antiinflammatory cytokines) in LPS-activated cells [3]. Phytochemicals also induced molecular changes in NF-Kb pathways [4], therefore, applying materials possessing the ability to suppress NF-kB signaling would be promising diet supplements in poultry husbandry since NF-Kb supports the expression of different inflammatory cytokines and chemokines, inclusive of genes related to cellular transformation, inflammation, invasion, and metatastasis [5]. The expression of genes related to tissue repair and inflammation is dependent on the time, strength and the site of stimulation, hence when birds are infected, it generates pro-inflammatory cytokines and mitogen that activate the expression of NFKB which is quickly followed by inflammatory cytokines [6].The NF-kb mediated pathways involves many physical reactions and is extremely important in the modulation of immunity, inflammation and apoptosis [7]. Interlukin 1 (IL1 $\beta$ ), Interleukin 6 (IL6) and tumor necreotic factor alpha are three known proinflammatory cytokines expressed in monocytes and macrophages after invasion of pathogens are identified [2,3]. These cytokines mediates metabolic changes that end up boosting immune response and resistance to diseases, thereby stunting growth and performance [2, 3]. Reports indicated a strong relationship between the levels of IL $1 \beta$ and the amount of intestinal inflammation in chickens, making IL1 $\beta$ the chief cytokine responsible for the initiation and multiplication of the inflammatory responses [8]. On the other hand, IL-10 helps in promoting the development of T2 responses which makes it inhibits the synthesis of pro-inflammatory cytokines inclusive of IL1 $\beta$ both at the level of transcription and post-transcriptionally, thereby down regulating inflammatory T1 responses and boosting erythrocyte immunity capacity [9]. IL-10 is been regarded as the signature member of the cytokines because it modifies immune response through direct effects on many cell types, hence low level of IL10 increases resistance in chickens while high levels increases susceptibility to intracellular pathogens since the level of pathogen correlates with the magnitude of Tcell response [10, 11]. In chickens, the spleen act as both reservoir and activation site for leukocytes and therefore an analysis of the mRNA levels in the spleen should be reliable in ascertaining systemic immune function [12]. There have been great breakthroughs in the past using various techniques and feed additives to achieve more cost effective and higher genetic potentials in poultry production. Antibiotics have been in livestock feed including poultry diets for a long period of time to prevent diseases, promote growth and improve feed conversion efficiency [13]. Antibiotics have also been known to have antibacterial effect and improved digestibility and performance of birds $[14,15]$. The continuous and prolonged use of antibiotics has resulted to deposition of residues in animal products including milk and meat [16] and the resistance among enteric bacteria as well as the transference of antibiotic resistance from livestock to man [17, 18]. These health hazards [19] have led to discontinued use of antibiotics and in some countries, and Europe total ban, and this has resulted to a new search for natural alternatives [16]. Plant derived products have been reported to contain less toxic substances than antibiotics, and scent leaf (Ocimum gratissimum L) is a good example of Herbs and spices that possess antimicrobial, antioxidative, anti-inflammatory, as well as immuno-modulatory properties [20]. Scent leaf is a leafy vegetable, and good source of dietary fibre, carotenoids, vitamin $\mathrm{C}$, foliate, phytochemicals and certain minerals [21]. Phytochemical analysis of the leaf extract shows the availability of steroids, flavonoids, alkaloids, saponins, tannins, terpenoids, cardiac glycosides and anthraquinone [22-24]. There is however, inadequate research information on the effect of Ocimum gratissimum on the immunomodulation in the chicken. This study was therefore designed to examine the role of scent leaf meal in the expression of immune genes in chicken spleen.

\section{MATERIALS AND METHODS}

\subsection{Experimental site, Animals and Diets}

The study was carried out at the Poultry Unit of the Teaching and Research Farms of Delta State College of Education Mosogar. One Hundred and Fifty (150) day old unsexed and healthy commercial broiler chicks, including 75 Cobb 500 and 75 Arbor Acre strains were sourced from Zartech Farms, Ibadan, Nigeria. The birds 
were raised on deep-litter system, and fed for a period of eight weeks (56 days). Feed and water were provided adlibitum throughout the experimental period. Scent leaves were harvested from a farm at Oki, Agbor, in Ika South Local government Area, Delta State, Nigeria. The leaves were air dried while still showing greenish coloration. The dried Scent leaves were hammer milled to obtain a final leaf meal. Five (5) Experimental broiler starter and finisher diets were formulated, and scent leaf meal was incorporated at the rate of $0.00 \%, 0.50 \%, 1.00 \%, 1.50 \%$ and $2.00 \%$ dietary levels in five (5) treatments as Treatment 1, Treatment 2, Treatment 3, Treatment 4 and Treatment 5 respectively.

\subsection{Experimental Design}

The 15obirds were randomly allotted into five dietary treatment groups of 75 birds per strain. Each strain had 15 birds per treatment. The birds in group I (T1) were given normal medications for broilers [25], while birds in groups II (T2), III (T3), IV (T4) and V (T5) had Scent leaf meal included in their feed at the rate of $0.50 \%, 1.00 \%$, $1.50 \%$ and $2.00 \%$ respectively.

\subsection{Sample Collection}

Three birds from each of the treatment groups were slaughtered at 4weeks (28days) and at the end of the feeding trial 8 weeks (56 days) to examine the mRNA expression patterns of genes regulating immune responses in Chicken. The spleen was collected from the experimental birds and stored in eppendorf tubes with the aid of RNALater solution and stored in a freezer prior to RNA extraction.

\subsection{RNA Concentration and Reverse Transcription}

RNA was extracted from a $25 \mathrm{mg}$ tissue in a mixture of $400 \mathrm{ll} \mathrm{RB}$ buffer and $\beta$-mertacaptoethanol. The total RNA extraction protocol as contained in Geneaid was then followed. The concentration and purity of the isolated RNA were assessed by a spectrophotometer (Nanodrop) followed by reverse transcription. The $20 \mu \mathrm{L}$ reverse transcription reaction system was comprised of the following: $10 \mu \mathrm{l}$ of RNA, $0.5 \mu \mathrm{L}$ of Oligo dT, $0.5 \mu \mathrm{L}$ of random primers, $5 \mu \mathrm{L}$ of nuclease-free water, $1 \mu \mathrm{l}$ of FIREScript Reverse Transcriptase, $0.5 \mu$ l RiboGrip RNAs inhibotor, $2 \mu \mathrm{l}$ 10x RT reaction buffer with DTT and $0.5 \mu \mathrm{L}$ of DNTP mix. The reaction procedure was performed under the following conditions: denaturation for $5 \mathrm{~min}$ at $70^{\circ} \mathrm{C}$, Primer annealing for $5 \mathrm{~min}$ at $25^{\circ} \mathrm{C}$, reverse transcription at $40^{\circ} \mathrm{C}$ for 20 mins followed by enzyme inactivation at $85^{\circ} \mathrm{C}$ for $5 \mathrm{mins}$ and then storage at $4{ }^{\circ} \mathrm{C}$.

Table-1. Primer sequence for real-time PCR

\begin{tabular}{|c|c|c|c|c|c|}
\hline $\mathbf{S} / \mathbf{N}$ & Genes & $\mathbf{F} / \mathbf{R}$ & Primer sequences for Chicken & NCBI accession number & $\% G C$ \\
\hline \multirow[t]{2}{*}{1} & IL1B & $\mathrm{F}$ & 5'GTCAACATCGCCACCTACAA3' & NM_204524.1 & 50 \\
\hline & & $\mathrm{R}$ & 5'CGGTACATACGAGATGGAAACC3' & & 50 \\
\hline \multirow[t]{2}{*}{2} & IL10 & $\mathrm{F}$ & 5’AGCTGAGGGTGAAGTTTGAG3' & NM_001004414.2 & 48 \\
\hline & & $\mathrm{R}$ & 5'AACTCATCCAGCAGTTCAGAG3' & & 50 \\
\hline \multirow[t]{2}{*}{3} & NFkB1 & $\mathrm{F}$ & 5'CCТCAACCТCACTТССТТАСТ Сз' & NM_205134.1 & 48 \\
\hline & & $\mathrm{R}$ & 5'CTTCAGTGTCCAGTCCTTTGT3' & & 50 \\
\hline \multirow[t]{2}{*}{4} & $\mathrm{NFkB} 2$ & $\mathrm{~F}$ & 5'GACATTGAGGTGCGGTTCTAT3' & NM_204413.1 & 50 \\
\hline & & $\mathrm{R}$ & 5'GATGGCGTACTGCTTGTGTA3’ & & 50 \\
\hline \multirow[t]{2}{*}{5} & GAPDH & $\mathrm{F}$ & 5’CCTCTCTGGCAAAGTCCAAG3’ & NM_204305.1 & 45 \\
\hline & & $\mathrm{R}$ & 5'CATCTGCCCATTTGATGTTG3' & & 55 \\
\hline
\end{tabular}

Note: IL1B: Interleukin1beta; IL10: Interleukin 10; NF-kB1: Nuclear Factor Kappa B1; NF-kB2: Nuclear Factor Kappa B2; F: Forward, R: Reverse; GC: Guanine-Cytosine content

\subsection{Real-Time Polymerase Chain Reaction}

Table 1 shows the genes, sequences (forward and reverse), guanine-cytocine content, and gene bank accession numbers of the primers used for the study. The mRNA expression level of Interleukin 1-beta, Interleukin 10, NF$\mathrm{kB} 1$, and NF-kB2 were measured using a 7500 Real-Time PCR System with a $20 \mu \mathrm{L}$ reaction system containing the 
following: $1 \mu \mathrm{L}$ of cDNA, $10 \mu \mathrm{L}$ of $2 \times$ SYBR Premix Dimer Eraser, $0.6 \mu \mathrm{L}$ of each gene specific primer $(100 \mathrm{nM})$ and $7.8 \mu \mathrm{l}$ nuclease free water. The reaction procedure were performed as follows: 1 cycle of $95^{\circ} \mathrm{C}$ for 30 secs followed by 39 cycles of $95^{\circ} \mathrm{C}$ for 5 secs, $60^{\circ} \mathrm{C}$ for 30 secs, and $72^{\circ} \mathrm{C}$ for 60 secs; and 1 cycle of $95^{\circ} \mathrm{C}$ for $15 \mathrm{secs}, 60^{\circ} \mathrm{C}$ for 60 secs, $95^{\circ} \mathrm{C}$ for 30 secs, and $60^{\circ} \mathrm{C}$ for 15 secs.

\subsection{Statistical Analysis}

All data collected were subjected to ordinary two-way analysis of variance (ANOVA) with the Prism 7.0 software (Graphpad Software Inc, San Diego, California). Multiple comparisons were corrected using the Bonferroni's method.

\section{RESULTS AND DISCUSSION}

Figure 1 and Figure 2, shows the expression patterns of interleukin $1 \beta$ in the spleen of chickens fed varying levels of Ocimim gratissimum leaf meal at 28days and 56days in two chicken strains. Interleukin $1 \beta$ expression patterns decreased with increased inclusion rate of the test ingredients at 28 and 56 days in both chicken strains. The expression of IL1 $\beta$ in the Arbor-acre strain was significantly different $(\mathrm{P}<0.05)$ for the control and treated groups, but treated groups did not differ significantly $(\mathrm{P}<0.05)$ at 56days, while $\mathrm{T} 1$ and $\mathrm{T} 2$ significantly differed $(\mathrm{P}<0.05)$ from T5; T3, T4 and T5 did not significantly differ $(\mathrm{P}>0.05)$ from each other at 28days. However, in Cobb500, T1 significantly differed $(\mathrm{P}<0.05)$ from $\mathrm{T} 1$, but not $\mathrm{T} 3, \mathrm{~T} 4$ and $\mathrm{T} 5$ at 28 days and 56days respectively. At 56 days, IL $1 \beta$ was expressed in 1.5 folds and 2.19 folds at $0.5 \%$ inclusion rate compared to $2 \%$ and down-regulated by 0.67 folds and 0.46 folds at $2 \%$ inclusion rate compared to $0.5 \%$ inclusion in the Abor-acre and Cobb 500 strain. In Figures 3, and 4, the relative expression of interleukin 10 shows significant differences $(\mathrm{P}<0.05)$ for the two strains at both time point, however, expression patterns were inconsistent at all ages in the two strains, while increased inclusion rate increased fold change in Abor-acre at 28days and 56days, in Cobb500, increased inclusion reduced expression of IL10 at 56days, but increased IL10 expression at 28days. IL10 was expressed in 0.05folds and 5.71 folds at $0.5 \%$ inclusion rate compared to $2 \%$ and up-regulated by 19.43 folds and 0.17 folds at $2 \%$ inclusion rate compared to $0.5 \%$ inclusion in the Abor-acre and Cobb 500 strain at 56days respectively. Figures 5, and 6, shows the expression patterns of Nuclear Factor Kappa B (NF-KB1) in two chicken strains at different time point. The control (T1) was significantly different $(\mathrm{P}<0.05)$ from other groups at 28days and 56days in the Arbor-acre, while $\mathrm{T} 1$ and T2 differed significantly from other groups at 56days in Cobb500; T1 and T4, as well as T2 and T3, were not significantly different $(\mathrm{P}>0.05)$, but other groups showed significant differences $(\mathrm{P}<0.05)$ at 28 days. $\mathrm{NF}-\mathrm{KB} 1$ was expressed in 58.41 folds and 2.24 folds at $0.5 \%$ inclusion rate compared to $2 \%$ and down-regulated by 0.02 folds and 0.45 folds at $2 \%$ inclusion rate compared to $0.5 \%$ inclusion in the Abor-acre and Cobb 500 strain at 56 days. The effect of dietary inclusion of Ocimum graticimum leaf meal on expression of NF-KB1 and IL10 was not consistent in the experimental birds at both ages, since results shows that increased inclusion did not constantly reduce or increase expression patterns of the gene for the two strains studied. Figures 7 , and 8 , shows the expression patterns of $\mathrm{NF}-\mathrm{KB} 2$ in two chicken strains at 28 and 56 days of age. $\mathrm{NF}-\mathrm{KB} 2$ was differentially expressed in both time points in the strains studied. Non-significant difference $(\mathrm{P}>0.05)$ was recorded for $\mathrm{T} 1$, T3 and T4, while significant differences $(\mathrm{P}<0.05)$ were obtained at 56days, while $\mathrm{T} 1$ was not significantly different $(\mathrm{P}>0.05)$ from T2 and T3. T3 and T4 followed the same trend, while significant differences $(\mathrm{P}<0.05)$ were recorded for other groups at 28days. NF-KB2 expression was not significant for T2 and T3, while other groups reported significant differences $(\mathrm{P}<0.05)$ at 56 days in the Cobb500 strain, but at 28 days, $\mathrm{T} 1$ and $\mathrm{T} 4$, T2 and T3 were not significant $(\mathrm{P}>0.05)$, while significant differences $(\mathrm{P}<0.05)$ were obtained for other groups. NF-KB2 was expressed in 0.12 folds and 2.44 folds at $0.5 \%$ inclusion rate compared to $2 \%$ and up-regulated by 8.31 folds and 0.14 folds at $2 \%$ inclusion rate compared to $0.5 \%$ inclusion in the Abor-acre and Cobb 500 strain respectively. 


\section{Interleukin1-beta (A)}
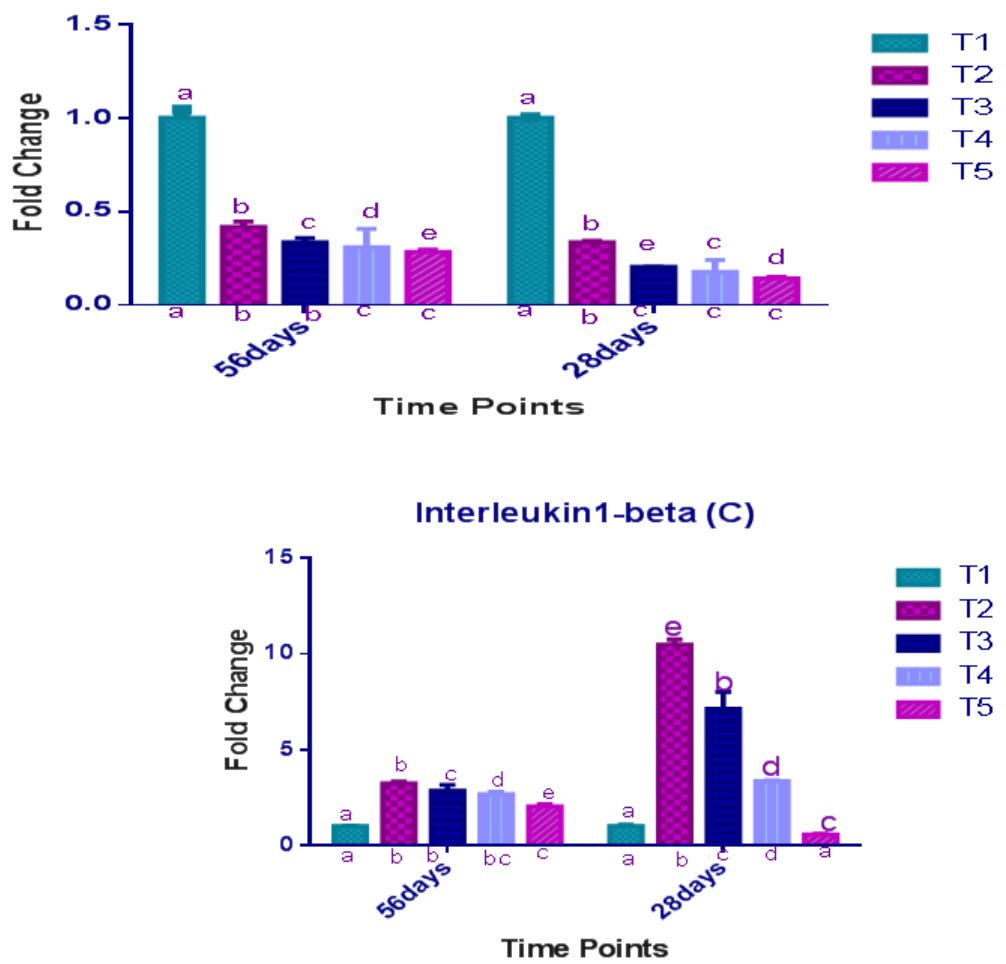

Figure-1 \& Figure-2. Relative expression pattern of interleukin 1-beta (IL 1B) in the spleen of Arbor-acre (A) and Cobb500 (C) strains at 28 days and 56 days. abcde- bars with different superscript between time points were significantly different $(\mathrm{P}<0.05)$, while bars carrying different subscript within same time points were significantly different $(\mathrm{P}<0.05)$. 2-way ANOVA test was done with multiple comparisons corrected using Bonferroni's method.

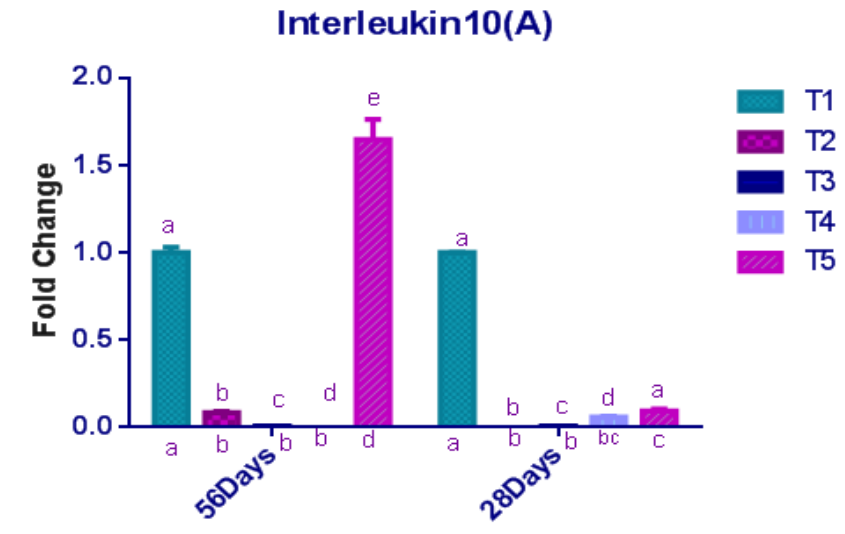

Time Points

Interleukin10(C)

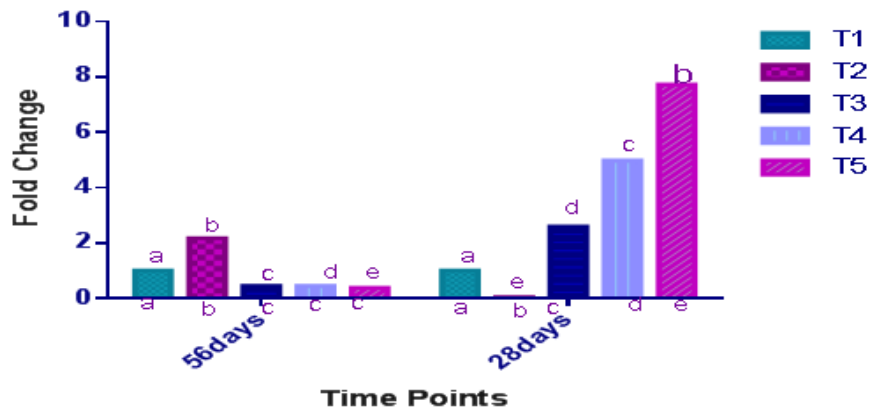

Figure-3 \& Figure-4. Relative expression pattern of interleukin 10 (IL 10) in the spleen of Arbor-acre (A) and Cobb500 (C) strains at 28 days and 56 days. abcde- bars with different superscript between time points were significantly different $(\mathrm{P}<0.05)$, while bars carrying different subscript within same time points were significantly different $(\mathrm{P}<0.05)$. 2-way ANOVA test was done with multiple comparisons corrected using Bonferroni's method. 


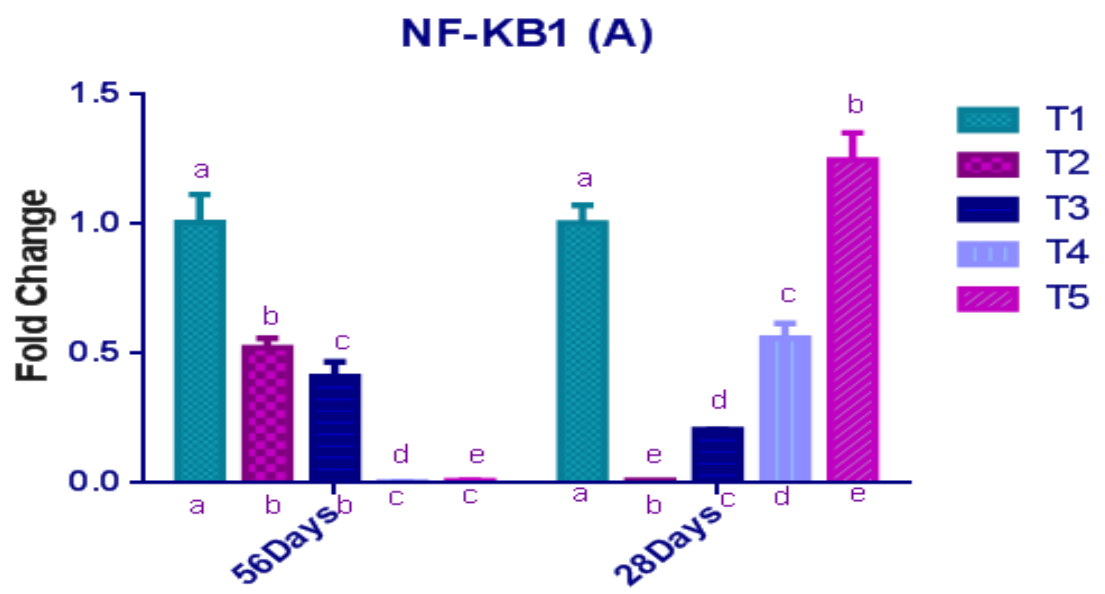

Time Points

NF-KB1 (C)

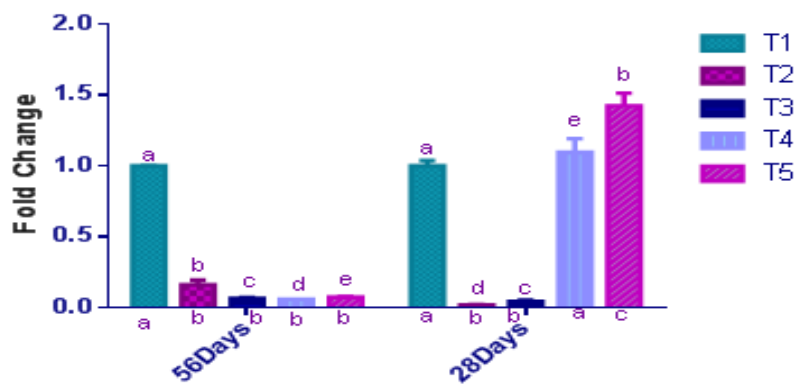

Time Points

Figure-5 \& Figure-6. Relative expression pattern of Nuclear factor kappa B1 (NF-KB1) in the spleen of Arbor-acre (A) and Cobb500 (C) strains at 28 days and 56 days. abcde- bars with different superscript between time points were significantly different $(\mathrm{P}<0.05)$, while bars carrying different subscript within same time points were significantly different $(\mathrm{P}<0.05) .2$-way ANOVA test was done with multiple comparisons corrected using Bonferroni's method.
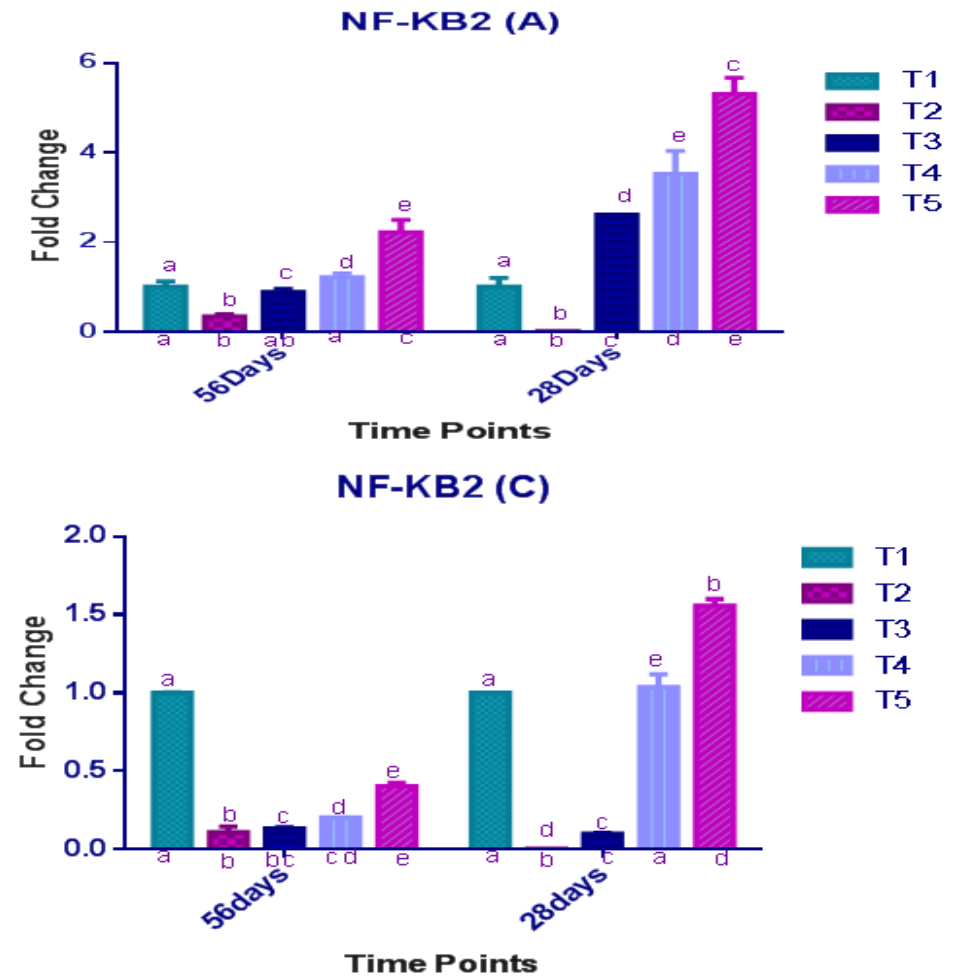

Figure-7 \& Figure-8. Relative expression pattern of Nuclear factor kappa B2 (NF-KB2) in the spleen of Arbor-acre (A) and Cobb500 (C) strains at 28 days and 56 days. abcde- bars with different superscript between time points were significantly different $(\mathrm{P}<0.05)$, while bars carrying different subscript within same time points were significantly different $(\mathrm{P}<0.05)$. 2-way ANOVA test was done with multiple comparisons corrected using Bonferroni's method. 


\section{DISCUSSIONS}

Knowing full well that birds can ingest feeds that may contain both nutrients and non-nutrient that can pose positive or negative effects, the intestinal wall becomes the first barrier to entertaining such effects. These consumed feeds can cause stress to birds that will trigger immune responses that are caused by the release of pro and anti-inflammatory cytokines. Inflammation necessitates cells to hire more cells to the centre of activity by the way of secreting inflammatory cytokines and chemokines, however, delayed inflammation can cause the animals to lose weight due to high energy expended in the process. Therefore, to ease and obstruct too much inflammation while bringing the immune system to standard state is vital to livestock production (2). Phytochemicals have been reported to decrease the expression of pro-inflammatory cytokines IL1 $\beta$, IL6 and TNF and increase antiinflammatory cytokines IL-10 in LPS-activated cells (3), which is in tandem with the present study as increased inclusion of dietary Ocimum gratissimum consistently reduced expression of interleukin $1 \beta$ in the spleen of the two chicken strains studied. The effect of strains in response to dietary levels were significant $(\mathrm{P}<0.05)$ at both time points. This is in line with previous studies that cytokine expression differs with type of bird as reported for layers and broilers [26, 27]. This could be attributed to the different responses in the immune systems of the chicken strains to the test ingredients. Although lack of sufficient antioxidants to eliminate reactive oxygen species can also trigger inflammation due to oxidative damage [2, 9, 28], hence, while including ingredients that improves antiinflammatory responses in chicken diets, the antioxidant capacity needs to be put into consideration in other to avoid oxidative damages. As a compliment and justification that the test ingredients covers this aspects, earlier reports indicated that compounds from medicinal plants reduced small intestine legions, reduced oxidative stress and improved body weight in chickens challenged with coccidial infection [20, 29]. This study is also in agreement with reports that Scent leaf (Ocimum gratissimum L) possesses antimicrobial, antioxidative, anti-inflammatory, as well as immuno-modulatory properties [20]. The anti-inflammatory role of Scent leaf was evident, as increased inclusion rate consistently down regulated IL $1 \beta$, which is known to be the chief pro-inflammatory cytokine in cells. Lactobacillus species was also found to differentially induced IL-10 and IL1 $\beta$ in spleen cells (8). Since one of the biological effects of IL-1 $\beta$ is to stimulate inflammation by activating the immune system in an acute phase response [30], dietary inclusion of scent leaf can be used in place of antibiotics to reduce inflammation in chickens thereby curbing stunted growth, excessive energy expenditure, and weight loss in birds. IL-10 together with 1L4 helps in promoting the development of T2 responses which makes it inhibits the synthesis of pro-inflammatory cytokines inclusive of IL1 $\beta$, TNF and IL12 both at the level of transcription and post-transcriptionally, thereby down regulating inflammatory $\mathrm{T} 1$ responses and boosting erythrocyte immunity capacity (9). IL-10 is been regarded as the signature member of the cytokines because it modifies immune response through direct effects on many cell types; this corresponds with the present study as results indicated a decrease in the expression of IL1 $\beta$, as IL10 levels increased in chicken spleen at 28 and 56days in the experimental birds in both strains studied. Ocimum gratissimum increased IL10 expression while simultaneously decreasing IL1 $\beta$ as observed in the current study. The anti-inflammatory response of the test ingredient is vital for averting weight loss and stabilizing growth rate in chickens if they are eventually faced with pathogen invasion. Bearing in mind that IL10 is the signature member of anti-inflammatory cytokines, higher amount of inclusion of the test ingredients in the diets of chickens may further strengthen the fight against inflammation in chicken, which invariably will result in body weight and growth stability. The differential expression of cytokines is not new as non antibiotic alternatives have previously been reported to significantly affect cytokine gene expression in coccidia challenged chickens [31]. While NF-kB2 consistently increased with increased inclusion rate of the test ingredient, NF-kB1 expression was affected in no specific direction. Reports indicate that phytochemicals have induced molecular changes in Nf-Kb pathways (4), but the directions and dimensions were unstable in this study. Carvacoal, cinnamaldehyde, curcumin and thymol were reported to surpress NF-kB expression [32-35], while our study shows NF-kB1 and NF-kB2 did not progress in the same manner with respect to the test ingredient. Earlier studies indicates that NF-kB can be induced and 
activated by pro-inflammatory cytokines, it has also been shown that NF-Kb activation increased production of proinflammatory cytokines that eventually resulted to systemic inflammation during stress period among birds [36]. Eimeria Tenella challenged birds increased expression of NF-kB together with other pro-inflammatory cytokines in chickens [37]. Therefore, reduced IL1 $\beta$ and NF-kB1 expression with increased levels of Ocimum gratissimum in the diet of the experimental birds is expected to down-regulate the expression of NF-kB2 in this study, but the reverse was the case in the expression of $\mathrm{NF}-\mathrm{kB} 2$ at 28 and 56 days. More so, applying materials possessing the ability to suppress NF-kB signaling would be promising diet supplements in poultry husbandry since NF-Kb supports the expression of different inflammatory cytokines and chemokines, inclusive of genes related to cellular transformation, inflammation, invasion, and metatastasis (5). Since the expression of genes related to tissue repair and inflammation is dependent on the time, strength and the site of stimulation (6), the expression of $\mathrm{NF}-\mathrm{kB} 1$ and $\mathrm{NF}-\mathrm{kB} 2$ in the current study could have been modulated by the test ingredient in different directions with respect to the NF-kB pathways.

\section{CONCLUSION}

This study further provides information on the anti-inflammatory roles of phytochemical containing plants in the immune system of chickens. It reveals that Ocimum graticimum can be used in place of antibiotics in broiler diet, which can reduce the negative effects occasioned by the use synthetic antibiotics.

Funding: This research work was funded by the Tertiary Education Trust Fund grant reference number: TETFUND/DESS/COE/MOSOGAR/IBR/2015/VOL.1

Competing Interests: The authors declare that they have no competing interests.

Acknowledgement: All Authors appreciate the Delta State College of Education Mosogar, and the management, and staff of African Biosciences limited Ibadan, for providing them with lab space and reagents.

\section{REFERENCES}

[1] J. Schulzke, S. Ploeger, M. Amasheh, A. Fromm, S. Zeissig, and H. Troeger, "Epithelial tight junctions in intestinal inflammation," Annals of the New York Academy of Sciences, vol. 1165, pp. 294-300, 2009.

[2] C. M. Huang and T. T. Lee, "Immunomodulatory effects of phytogenics in chickens and pigs — A review," AsianAustralasian Journal of Animal Sciences, vol. 31, pp. 617-627, 2018.Available at: https://doi.org/10.5713/ajas.17.0657.

[3] K. Ghareeb, W. A. Awad, C. Soodoi, S. Sasgary, A. Strasser, and J. Böhm, "Effects of feed contaminant deoxynivalenol on plasma cytokines and mRNA expression of immune genes in the intestine of broiler chickens," PLoS One, vol. 8, p. e71492, 2013.Available at: https://doi.org/10.1371/journal.pone.0100051.

[4] M. Lee, W. Lin, S. Wang, L. Lin, B. Yu, and T. Lee, "Evaluation of potential antioxidant and anti-inflammatory effects of Antrodia cinnamomea powder and the underlying molecular mechanisms via Nrf2-and NF- $\mathrm{BB}$-dominated pathways in broiler chickens," Poultry Science, vol. 97, pp. 2419-2434, 2018.Available at: https://doi.org/10.3382/ps/pey076.

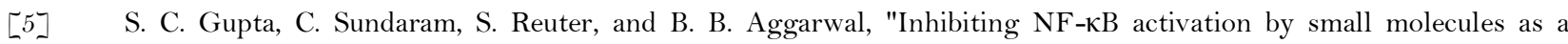
therapeutic strategy," Biochimica et Biophysica Acta (BBA)-Gene Regulatory Mechanisms, vol. 1799, pp. 775-787, 2010.Available at: https://doi.org/10.1016/j.bbagrm.2010.05.004.

[6] R. Ravi, G. C. Bedi, L. W. Engstrom, Q. Zeng, B. Mookerjee, C. Gélinas, E. J. Fuchs, and A. Bedi, "Regulation of death

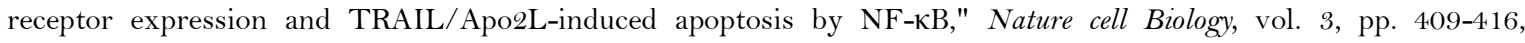
2001.Available at: https://doi.org/10.1038/35070096.

[7] S. E. Byeon, Y.-S. Yi, J. Oh, B. C. Yoo, S. Hong, and J. Y. Cho, "The role of Src kinase in macrophage-mediated inflammatory responses," Mediators of Inflammation, vol. 2012, pp. 1-18, 2012.Available at: https://doi.org/10.1155/2012/512926. 
[8] B. T. Jennifer, J. Gong, P. Parvizi, and S. Sharif, "Effects of lactobacilli on cytokine expression by chicken spleen and cecal tonsil cells," Clinical and Vaccine Immunology, vol. 17, pp. 1337-1343, 2010.Available at: https://doi.org/10.1128/cvi.00143-10.

[9] S.-C. Fang, C.-L. Hsu, and G.-C. Yen, "Anti-inflammatory effects of phenolic compounds isolated from the fruits of Artocarpus heterophyllus," Journal of Agricultural and Food Chemistry, vol. 56, pp. 4463-4468, 2008.

[10] K. W. Moore, R. de Waal Malefyt, R. L. Coffman, and A. O'Garra, "Interleukin-10 and the interleukin-10 receptor," Annual Review of Immunology, vol. 19, pp. 683-765, 2001.

[11] J. Bumstead, N. Bumstead, L. Rothwell, and F. Tomley, "Comparison of immune responses in inbred lines of chickens to Eimeria maxima and Eimeria tenella," Parasitology, vol. 111, pp. 143-151, 1995.

[12] S. Redmond, R. Tell, D. Coble, C. Mueller, D. Palić, C. B. Andreasen, and S. J. Lamont, "Differential splenic cytokine responses to dietary immune modulation by diverse chicken lines," Poultry science, vol. 89, pp. 1635-1641, 2010.Available at: https://doi.org/10.3382/ps.2010-00846.

[13] R. Engberg, M. Hedemann, T. Leser, and B. Jensen, "Effect of zinc bacitracin and salinomycin on intestinal microflora and performance of broilers," Poultry Science, vol. 79, pp. 1311-1319, 2000.Available at: https://doi.org/10.1093/ps/79.9.1311

[14] J. Dibner and P. Buttin, "Use of organic acids as a model to study the impact of gut microflora on nutrition and metabolism," Journal of Applied Poultry Research, vol. 11, pp. 453-463, 2002.Available at: https://doi.org/10.1093/japr/1 1.4.453.

[15] I. Aroniyo, "Dietary supplementation of probiotics and symbiotics on intestinal microbial Populations and gut morphology of turkey poults," MSc. Thesis, Department of Animal Science, University of Ibadan, 2014.

[16] C. T. Kamel, Tracing modes of action and the role of plant extracts in non-ruminants. In Garnsworthy, P. C. and Wiseman, J. (eds). Recent Advances in Animal Nutrition. Nottingham, UK: Nottingham University Press, 2001.

[17] F. Onwurah, G. Ojewola, and S. Akomas, "Effect of basil (Ocimum Basilicum L.) on coccidial infection in broiler chicks," Academic Research International, vol. 1, pp. 432-442, 2011.

[18] S. Mathur and R. Singh, "Antibiotic resistance in food lactic acid bacteria-a review," International Journal of Food Microbiology, vol. 105, pp. 281-295, 2005.

[19] B. O. Nweze and A. E. Nwankwagu, "Effects of Tetrapleuratetraptera under different feeding regimes on growth performance and gut microbes of broiler chicken," in Proc. 35th Conf. Nig. Soc. Anim. Prod. 14-17 March, 2010. Univ. of Ibadan, Nigeria, 2010 , p. 299.

[20] A. Sofowora, Medicinal plants and traditional medicine Africa. Ibadan. Nigeria: Spectrum Books Ltd, 1993.

[21] R. B. M. Wills, D. Graham, and D. Joyce, "Postharvest: An introduction to the physiology and handling of fruit vegetables and ornamentals," 4th ed Australia: CAB International, 1998, pp. 15-32.

[22] I. I. Ijeh, O. U. Njoku, and E. C. Ekenze, "Medical evaluation of Xylopiaaethiopica and osimumgratissimum," Journal of Medical Aromatics Science, vol. 26, pp. 44-47, 2004.

[23] K. O. Akinyemi, O. Oladapo, C. E. Okwara, C. C. Ibe, and K. A. Fasure, "Screening of crude extracts of six medicinal plants used in South-West Nigerian unorthodox medicine for anti-methicillin resistant Staphylococcus aureus activity," BMC Complementary and Alternative Medicine, vol. 5, pp. 1-7, 2005.Available at: https://doi.org/10.1186/1472-6882-5-6.

[24] A. C. Akinmoladun, E. Ibukun, E. Afor, E. M. Obuotor, and E. Farombi, "Phytochemical constituent and antioxidant activity of extract from the leaves of Ocimum gratissimum," Scientific Research and Essays, vol. 2, pp. 163-166, 2007.

[25] Ogbongenet, "Retrieved from https://www.nairaland.com/2513166/medication-vaccination-time-table-poultry [Accessed 6th September 2020]," 2015.

[26] O. Nielsen, P. Sørensen, J. Hedemand, S. Laursen, and P. H. Jørgensen, "Inflammatory response of different chicken lines and B haplotypes to infection with infectious bursal disease virus," Avian Pathology, vol. 27, pp. 181-189, 1998.Available at: https://doi.org/10.1080/03079459808419321. 
[27] L. V. Tatiana and K. C. Klasing, "Divergence of the inflammatory response in two types of chickens," Developmental ${ }^{2}$ Comparative Immunology, vol. 25, pp. 629-638, 2001 .Available at: https://doi.org/10.1016/s0145-305x(01)00023-4.

[28] A. C. Siani, M. C. Souza, M. G. Henriques, and M. F. Ramos, "Anti-inflammatory activity of essential oils from Syzygium cumini and Psidium guajava," Pharmaceutical Biology, vol. 51, pp. 881-887, 2013.Available at: https://doi.org/10.3109/13880209.2013.768675.

[29] R. Wallace, W. Oleszek, C. Franz, I. Hahn, K. Baser, A. Mathe, and K. Teichmann, "Dietary plant bioactives for poultry health and productivity," British Poultry Science, vol. 51, pp. 461-487, 2010.Available at: https://doi.org/10.1080/00071668.2010.506908.

[30] P. Wigley and P. Kaiser, "Avian cytokines in health and disease," Brazilian Journal of Poultry Science, vol. 5, pp. 1-14, 2003.Available at: https://doi.org/10.1590/s1516-635x2003000100001.

[31] L. Hang, S. A. Adedokun, L. Adeola, and K. M. Ajuwon, "Anti-inflammatory effects of non-antibiotic alternatives in coccidia challenged broiler chickens," The Journal of Poultry Science, vol. 51, pp. 14-21, 2014.Available at: https://doi.org/10.2141/jpsa.0120176.

[32] Y. Zou, Q. Xiang, J. Wang, J. Peng, and H. Wei, "Oregano essential oil improves intestinal morphology and expression of tight junction proteins associated with modulation of selected intestinal bacteria and immune status in a pig model," BioMed Research International, vol. 2016, pp. 1-11, 2016.Available at: https://doi.org/10.1155/2016/5436738.

[33] F. Roth-Walter, A. Moskovskich, C. Gomez-Casado, A. Diaz-Perales, K. Oida, J. Singer, T. Kinaciyan, H. C. Fuchs, and E. Jensen-Jarolim, "Immune suppressive effect of cinnamaldehyde due to inhibition of proliferation and induction of apoptosis in immune cells: Implications in cancer," PloS one, vol. 9, p. e108402, 2014.Available at: https://doi.org/10.1371/journal.pone.0108402.

[34] A. Lubbad, M. Oriowo, and I. Khan, "Curcumin attenuates inflammation through inhibition of TLR-4 receptor in experimental colitis," Molecular and Cellular Biochemistry, vol. 322, pp. 127-135, 2009.Available at: https://doi.org/10.1007/s1 1010-008-9949-4.

[35] G. Kavoosi, J. A. Teixeira da Silva, and M. J. Saharkhiz, "Inhibitory effects of Zataria multiflora essential oil and its main components on nitric oxide and hydrogen peroxide production in lipopolysaccharide-stimulated macrophages," Journal of Pharmacy and Pharmacology, vol. 64, pp. 1491-1500, 2012.Available at: https://doi.org/10.1111/j.20427158.2012.01510.x.

[36] P. F. Surai, I. I. Kochish, and M. T. Kidd, "Redox homeostasis in poultry: Regulatory roles of NF-кB," Antioxidants, vol. 10, p. 186, 2021 .Available at: https://doi.org/10.3390/antiox 10020186.

[37] H. Jin, Y. Haicheng, Z. Caiyun, Z. Yong, and W. Jinrong, "The expression of NF-kB signaling pathway was inhibited by silencing TGF-b4 in chicken IECs infected with E. tenella," Brazilian Journal of Poultry Science, vol. 22, pp. 1-8, 2020.Available at: http://dx.doi.org/10.1590/1806-9061-2020-1338. 